\title{
A Double-Edged Sword? Reflections on the Development of the San Community of Botswana
}

\author{
Kenneth B. Dipholo (Dr):
}

\author{
Department of Adult Education, University of Botswana \\ dipholok@mopipi.ub.bw
}

Ndwakhulu Tshishonga (Mr):

\author{
School of Social Work \& Community Development, University of KwaZulu-Natal
}

Tshishonga@ukzn.ac.za

Nyawo Gumede (Mr):

Tshwane University of Technology

GumedeNB@tut.ac.za

Doi:10.5901/mjss.2014.v5n20p2926

\begin{abstract}
A large part of the discourse of development envisages a symbiotic relationship between development and democracy, with some theorists and practitioners arguing that there is a strong positive relationship between development and democracy. In particular, it is presumed that both development and democracy inform and blend into one another. Essentially, democracy is believed to be a basic requirement for development as well as an indicator of it. Significantly, the very idea that democracy is a prerequisite or a basic pre-condition of development is symbolically important and suggests that development is fundamentally founded on a healthy democratic tradition. In similar manner, high levels of development are presumed to give impetus to democratic impulses. It is thus widely presumed that economic development provides impetus to the transformation of political systems and the full enjoyment of human rights. Perhaps this position is a result of the growing realization that problems of economic performance and governance are interconnected, such that solution to one of the problems may often be found in the solution to the other. This paper seeks to present a cautionary perspective on this widely accepted position by arguing that while the two inform and blend into one another, the outcome may not always be desirable or beneficial. Using the right based approach to development as the conceptual framework the paper presents a critical assessment of this relationship, noting that in some instances, development interventions have had negative effects on basic civil and political freedoms of the San people of Botswana.
\end{abstract}

Keywords: development; democracy; human rights; right-based approach; San; Botswana

\section{Introduction}

The basic objective of development is to expand people's choices by providing equality of opportunity for all people in society, sustaining such opportunities from one generation to the next and empowering people to participate in and benefit from development processes (Human Development Report, 1995: 1). This definition implies that development is not measured only according to economic indicators such as GDP and GNP but also according to health (life expectancy and education literacy and enrolment). Development is a holistic process that integrates economic, social, political, cultural and environmental needs of people to promote improvement in the quality of life for all.

It could therefore be argued that the primacy of development is people. Within this framework, people are considered to benefit and enhance their living standards as a result of development. More importantly, development should serve the needs and interests of those who have been historically marginalized as a result of structural inequalities. Thus, every community desires a healthy and prosperous life, significantly in terms of their own interpretation. This implies that development interventions that do not accord with the aspirations of the beneficiaries may be undesirable in spite of their noble intentions.

Democracy is generally accepted as the ideal method of running a country because it ensures political stability necessary for economic prosperity and the protection of rights. It provides for state accountability and efficient use of 
resources. This depiction of the concept of democracy invariably connects it to a desire by those who practice democracy to nurture requisite conditions for a better life. In a sense, by definition, democracy facilitates the social, political, environmental and economic development of societies. In like manner, development as a holistic process incorporates political goals. However, this paper seeks to argue that development that is often imposed by an authoritarian developmental state may have detrimental effects on expected beneficiaries. The paper examines the Government of Botswana's approach to developing the San people and contends that a strong developmental state that has become arrogant and authoritarian by virtue of its domineering role in national development could often become tyrannical especially to peripheral communities.

The paper starts by presenting a theoretical conception of some of the development theories ranging from modernization theory through to the Basic Needs approach. The next section present Botswana as a developmental state with to asserting that by its nature, a developmental state could often metamorphoses into an oppressive regime in its endeavour to develop its people. The paper then introduces the concept of democracy and the connection between development and democracy. The next section discusses the right based approach to development and the rights of the San in the context of state-sponsored development asserting that a right based approach to development essentially obliges the state to protect the rights and interests of beneficiaries of development something which has been absent in respect of the development of the San. The Dilemmas inherent in the connection between democracy and development in respect of the development of the San are outlined leading to question whether the circumstances within which the San found themselves in could be ripe for insurrection. The discussion closes with a conclusion cautiously pointing out that perhaps the state-sponsored development of the San is to some extent a source of their underdevelopment.

\section{Conceptualizing development paradigms}

Various theorists have over the years provided different understandings and interpretations in their attempt to demystify the concept of development. Perhaps a notable definition for the purposes of this paper is one provided by the South Commission Report (1990:10) Development in this report is viewed as:

As a process that enables human beings to realise their potential, build self-confidence and lead lives of dignity and fulfilment. It is a process that frees people from the fears of want and exploitation. It is a movement away from political, economic or social oppression. Through development political independence acquires its true significance. And it is a process of growth, a movement essentially springing from within the society that is developing.

Since there exist a variety of development theories including modernization theory, dependency theory, populism, basic needs theory and so forth, this paper argues that any approach to the development of a specific group of people must necessarily reflect their erstwhile way of life. This section looks at some of the theories of development with a view to illuminate this discussion.

\section{Modernization theories}

Modernization theories are theories that conceive development in terms of processes and stages through which traditional or backward societies were bound to follow during their transition to modern society (Larrain, 1989). The underlying assumption is that developing societies must repeat the same metamorphosis experienced by developed societies. In relation to local community development, the major assumption of modernization theory is that overall growth of the economy is a fundamental prerequisite for local community development and is the only strategy that would benefit everyone.

The assumption is that the benefits of the growth of the national economy will diffuse down to local communities so that every member of the community would inevitably experience an improved standard of living that would be accompanied by enhanced incomes.

However, critics, in particular Andre Gunder Frank, argue that the underdevelopment of local communities should not be justified in terms of an original and necessary condition that has also been experienced by developed societies. They argued that underdevelopment of local communities only makes sense as viewed in relation to the present situation that is depicted by the unequal relationship between developed societies and underdeveloped societies. Thus, tradition does not necessarily need to be destroyed or replaced with modernity to usher in a condition called development. Criticism of modernization theories culminated in the birth of a paradigm that construed the underdevelopment of local communities as a process that has been facilitated by deliberate domination by development planners in the whole process of development planning and management. 


\section{Dependency theories}

This school of thought presents a radical challenge to the teachings of modernization theorists. The key contention of dependency theorists is that the backwardness of local communities (as peripheral communities) is explicitly caused by their virtual dependence on urban economies or central economies. As more and more resources get siphoned from the country sides to the urban communities, local communities will continue to experience underdevelopment. This means that local rural communities are underdeveloped because of the transfer of their resources to urban communities.

Analysing the capitalist development model, Wallerstein (1989: 122) stresses that 'the key factor to note is that within a capitalist world economy, all states cannot develop simultaneously by definition, since the system functions by virtue of having unequal core and periphery regions'. Using this analysis, it can be argued that until rural local communities are targeted as a specific sector that requires targeted locally grounded interventions, their underdevelopment will persists. Since the urban centres developed on the basis of unequal relations, it would seem that for local communities to develop they need to exploit some other communities to advance their own development. This law of evolution seems fatally flawed in that poor local communities may not have the opportunity to exploit some other, presumably poorer, communities.

A significant criticism of dependency theory is that it has maintained the same theoretical frame of reference through its analysis of underdevelopment from the perspective of capitalist core-periphery relationship. Whereas it may be true that urban development has been at the expense of rural local development, it does not necessarily mean that the development of local communities cannot be achieved within a capitalist national economy. In other words, rural local communities do not need to be de-linked from the entire economic structure to attain development. Local communities will remain part and parcel of the broader national economic structure and to some extent will need influence of the urban economy in order to develop. However, what is paramount is that the development of local communities must not be dependent on prior development of urban communities nor should it be an incidental by-product of the growth of the national economy. Both can grow simultaneously and in partnership.

\section{Populism}

Significant concerns were that sections of the population in the country sides have not benefited as much from growth in national economies. Specific criticism of the dominant paradigms of development has been that they over-emphasize economic aspects of development. It has been argued in this essay that overall economic growth does not guarantee a simultaneous improvement in the standard of living of the majority of the people especially those who live in the country sides.

On the basis of this argument, the integration of economic and social aspects of development was highlighted after 'recognizing the necessary interaction of physical resources, technical processes, economic aspects and social change' (Esteva, 1997:14). In a way this point to reality that the transformation of rural local communities cannot be limited to an incidental process of diffusion of economic benefits, rather it requires deliberate and concerted efforts to focus on the use of existing local resources to promote local development. Studies have shown that poor people especially those in rural communities place more value on independence, self-respect and freedom to make their own decisions (Warren, 1995).

In view of these limitations, the United Nations proposed a unified approach to development and planning that would integrate both the social and economic aspects in the design of development programmes (Esteva, 1997). The approach is two-pronged; with a deliberate focus on people, and poor people first (Chambers, 1993) and a focus on the more established economic aspect which largely emphasis the provision of things. The Unified Approach was to encompass various components designed to:

- Leave no sector of the population outside the scope of change and development.

- Effect structural change which favours natural development and activate all sectors of the population to participate in the development process.

- Aim at social equity, including the achievement of an equitable distribution of income and wealth in the nation.

- Give high priority to the development of human potentials (Esteva, 1997).

These ideas ultimately converged into what came to be known as the human-centred development which represents a clear focus on people as subjects of the development process as well as beneficiaries. The approach entails the involvement of people at all stages of development planning in such a way that they are allowed and able to discover the possibility of exercising choice and therefore their abilities in managing their own development.

However, development plans, policies and programmes remained largely initiated by state officials for and on 
behalf of the local people. As a result of this controlled development, poverty and income inequalities have persisted and in some cases worsened leading to strong resentment against the human-centred approach.

\section{Basic Needs Approach}

In search for a more effective approach, the United Nations proposed the basic needs approach to essentially satisfy human basic needs in order for people, poor people especially, to cope with the challenges of hunger, deprivation and inequalities. Its apologists maintained that development interventions should be evaluated by the contribution they make in meeting the basic needs of the people, improving their life (Rogers, 1992).

A fundamental criticism of basic needs approach is that it focuses exclusively on meeting immediate human needs, not by the individual or community but by others who have the means and interest to do so. It is a charitable approach that does not seek to empower people. It is also based on the assumption that those who have means to help poor local communities are aware what poor people want. Thus, the needs of local communities in this respect are actually outsiderdefined. This approach may not reflect the actual needs of local communities and may in the long run exacerbates the poverty of local communities because it is essentially a process of doing for others, not helping them to do for themselves. The approach is also ridiculous because it seems to suggest that after meeting the limited basic needs, there is no further need for development. It is a disempowering approach that promotes the dependency syndrome.

As a result of the sustained criticism, development professionals became aware that while they possess significant knowledge and competences, they will nevertheless need the input of local people for meaningful development. In other words, development administrators had to accept that their knowledge of problems confronting local communities is limited and their prescriptions therefore may not always be right. This realization challenges the top-down, bureaucratic, mechanistic and centralized approach to the development of local communities and ushers in a new order in which the capacity of local communities to contribute to their own development is critical as Rogers (1992: 156) states that 'the biggest potential capital which a nation possess is its human population and thus we need to invest in this resource if we are to achieve economic growth'.

\section{Botswana as a developmental state}

A developmental state is defined as one in which the state is the primary agent of socio-economic change and actively organizes and directs it (Edge, 1998:333). In essence, a developmental state is characterized by having a strong state intervention in the promotion of national development. White (1992) categorizes a developmental state as representing the state in its developmental capacity: those specific institutions, ideas, and policy interventions which embody the socioeconomic aims and actions of a given state. In respect of Botswana, Tsie (1996: 601) comments that:

Since independence its bureaucratic and political elites have pursued a series of policies calculated to promote economic growth and development. In the process both elites acquired a developmental orientation. The bureaucratic elite in Botswana is powerful and generally effective in formulating and executing development policy. As a result, much of development that has occurred in Botswana is has been state-sponsored and directed. It is in this sense that one can speak of a developmental state in Botswana.

In similar ways, Edge (1998:336) holds the view that 'Within Botswana, the strength of the developmental state cab be noted in each sphere of social, political and economic life, from physical infrastructure to human resource development'. Essentially, the Botswana Government takes a leading role in the development process to a point where it could be characterized as an authoritarian government directing state machinery at every instance. However, a powerful and authoritarian that is at the centre of every major development initiatives is bound to become insensitive and repressive to some extent especially to social groups that are underprivileged and dependent on state hand-outs for their livelihoods, as shall be shown is subsequent discussions.

\section{The concept of democracy}

Democracy is a loaded concept that is often modelled and used at the convenience of time. It derives its meaning for the purpose at hand hence it never will and can never be interpreted to universal satisfaction. It could mean different things at different times to different people. However, in its simplest form, democracy is understood to mean rule by the people. However, the idea of democracy encapsulates key features that stand out as the cardinal principles of a healthy 
democracy. Principally, societies establish democratic governments for the protection and promotion of their rights, interests, and welfare. Democracy demands that citizens be free to participate in the activities of the state, suggesting that political freedom lies at the heart of the concept of democracy.

Fundamentally, democracy is pillared on the idea that citizens are the source of authority of government such that the powers of government should be based upon the consent of the governed. This being the case, it could be argued that people do not give power to government to oppress, harass, or trample on their interests and rights willy-nilly but rather to safeguard their fundamental rights and welfare. In particular, liberal democracy emphasizes that all persons have certain fundamental rights such as political freedom including safeguards against oppression of minority groups, freedom of expression, right to privacy and to a private sphere of life free from governmental interference and so forth, for which democracy is expected to protect.

\section{Development and democracy}

The connection between development and democracy may not always be apparent but what is not disputable is that to some degree both inform each other. For a majority of the people, democracy is meaningful if it delivers development in the same way as development would be fulfilling if people rights, interests and welfare are protected and promoted. However, Adejumobi (2000) points out that the nexus between democracy and development has remained contestable to date. Nevertheless, Adejumobi (2000) posits that liberal democracy provides the basic foundation for economic development in that libertarian values such as the protection of human rights, freedom of expression, the rule of law and so forth, create the institutional context and processes for economic development to take off.

In general, democracy provides political stability which in turn provides a stable investment climate and ensures mobilization of national energies and resources for economic development. To illustrate this perspective, Adejumobi (2000) made a comparison of countries with contrast political system. On the one hand, Botswana and Mauritius representing liberal democratic political system recorded rate of growth of Gross National Product (GNP) per capita of 8.4\% and 3.2\% respectively between 1965 and 1990 whereas The Democratic Republic of Congo and Nigeria representing non-democratic political systems recorded GNP per capita of $-2.2 \%$ and $0.1 \%$ respectively for the same period. While this contrast is not cast in stone, it nevertheless supports the view that democracy provides a conducive environment for development.

Nevertheless, Chen (2007) holds the view that the practice of democracy on its own does not constitute a magic wand for economic progress but that it is the content of democracy and the way it is constituted that has some implications for development. This view seems to marry with the concern that democracy is a normative concept which is often defined and applied at the convenience of a particular political regime. On this score, Adejumobi (2000) shares that the nature and constitution of democracy determines the extent to which the people participate concretely in decision making thus promoting sustainable development. Democracy in its constitutive elements must give practical expression to an organized and predictable life for the people, engender equity and fairness both in power and resource distribution, and facilitate the empowerment of the people (Adejumobi, 2000). It is through this that democracy as a system of government can provide a facilitative environment for development.

In similar lines of thought, it is argued that economic development precipitates democracy even though it is not a sufficient condition for democracy. Macionis (2008) contends that the quality of politics in the West is largely shaped by the free markets economic ideals. Thus, nations desire to have peace in order to attract development finance such that their quest for development requires that they promote political stability. Bhagwati (2002: 127) comments that:

Development is many sided; it is not just growth rates of income. True social needs such as public health, protection of the environment and the elimination or relief of extreme poverty cannot be provided unless governments have resources that growth can generate. But the use of those resources for such public needs will not automatically follow unless the political system permits and provides the incentives to mobilize and translate those needs into effective demands. I would say that democratic regimes that are characterized by structures and processes that provide effective access by the groups, often on the economic periphery, who are to profit most from those social programs are more likely to have such social needs translated into effective demands.

In similar ways, Charlton (1986: 7) reveals that most of the hard core of democracies - states with long histories of democratic competition and of political stability - are in the economically developed first world.

\section{The right-based approach and the rights of the San}

Kindornay (2012) posits that the rights based approach to development emerged as a new development paradigm in the 
late 1990s and was immediately distinguished for putting human rights at the heart of development. In accord to this opinion, Wilson (2005) also pointed out that the right based approach promotes justice, equality, freedom and tackles the power issues that lie at the root of poverty and exploitation. Mealan (2009) argues that the right based approach deals with identity politics used to refer to a geo-cultural category, presupposing a world collectively of 'indigenous people' in contrast to their various others. The rights-based approach is founded on the conviction that each and every human being by virtue of being human is a holder of rights. In consequence, a right entails an obligation on the part of the government to respect, promote, protect, and fulfill it.

Theis (2010) opines that placing the protection and realization of human rights at the center of development and progressively respecting, promoting and fulfilling such rights and obligations is the way to achieve human development. In similar disposition, scholars such as Wilson (2005), Ljungman (2004) and so forth contend that the right based approach is and must be accounted for as a conceptual framework for the pursuit of human development that is normatively based on international human rights standards and principles as the compass of development and developmental processes while local communities and international human rights obligations provide the objectives of development. In consort with this perspective is the UN training manual on the Rights Based Approach to Development Programming of (2002) which proclaims that the ultimate goal of development is to guarantee all human rights to everyone using human rights as both a vision and a set of tools to achieve human development.

As already stated earlier in this paper, development cannot be universally defined because it is subjective and discursively constructed (Mullick, 2005). Nevertheless, Theis (2010) argues that development is generally concerned with a particular set of goals among others, the distribution of resources and ensuring access to services, such as health, education, social welfare, poverty alleviation and income generation. The discussion of the Basic Needs Approach in this paper suggested that the approach which is at times derisively referred to as the charity approach, largely entails identifying the basic requirements of a particular group of people and subsequent palliative interventions aimed at fulfilling the needs. It has to be noted that such interventions are promulgated at the discretion of the government which implies that development in this respect has been conceptualized from the perspective and possibly the interest of government.

Johnson (2003: 47) comments that:

\begin{abstract}
...the basic needs approach often aims to obtain additional resources to help a marginalized group obtain access to services. A human rights approach, in contrast, calls for existing community resources to be shared more equally, so that everyone has access to the same services ...while a basic needs approach does not necessarily recognize willful or historical marginalization, a human rights approach aims directly at overcoming such marginalization....furthermore, basic needs can, in principle, be met through benevolent or charitable actions. Actions based on a human rights approach are based on legal and moral obligations to carry out a duty that will permit a subject to enjoy her or his right, .....accountability for such a duty depends partly on the duty-bearer's acceptance of responsibility. Charity negates such acceptance, as it does not take rights and responsibilities into consideration. In a rights approach, compassion and solidarity replace charity. A requirement of the human rights approach, then, is that insofar as possible, everybody must have a human rights "heart," reflected through decisions and actions. Decisions and actions must be taken in recognition that every human being is a subject of human rights, not an object of charity or benevolence. While charity often disempowers the poor and other vulnerable people, creating dependence, solidarity empowers people and enhances their capacity to improve the quality of their lives.
\end{abstract}

From the above extract, it could be argued that a right based approach involves not charity or simple social, economic and cultural development but a process of enabling and empowering those not enjoying their rights to claim them. Thus, the objectives of development are defined in terms of particular rights as legally enforceable entitlements linked to international, regional and national human rights instruments.

The San (or Basarwa) people of the Kalahari in Botswana are commonly known as Bushmen derived from their survival strategy of hunting wild game and gathering wild fruits. Over the years the San have slowly been pushed out of their erstwhile ancestral land by mainstream Tswana groups looking for fertile land. In more or less similar ways, the Botswana government has forced the San to relocate to permanent locations arguing that they needed to be civilized and be provided with modern education, running water, and other modern amenities. This resulted in dispossession of the San people's land often compounded by the reality that the San have no concept of private ownership hence they struggle to make legal claims to the land they had lived on for centuries. Braun \& Mulvagh (2008) asserts that indigenous communities have a unique culture and way of life that differs considerably from that of the dominant society. Fundamentally, indigenous communities such as the San depend for their on access and right to their traditional lands and natural resources thereon. Any significant variation to their access and right to their land is likely to have far reaching consequences on their ability to provide for themselves and survive in the long-term. However, the government of 
Botswana regards the concept of indigenous people and concomitant obligations as separatist (Saugestad, 2008). In specific terms, regard all ethnic groups as indigenous to the country hence does not recognize Basarwa as an indigenous minority requiring tailored development initiatives. A consequence of this policy posture is that the San are marginalized, impoverished and discriminated against largely owing to their perceived backwardness (Bojosi, 2009). Their forcible removal from the Central Kalahari Game Reserve and the government's decision to terminate the provision of certain basic and essential services within the Reserve including the provision of portable water as a way to coerce the San to relocate indicates the extent of their powerlessness and or the authoritarian nature of Botswana's developmental state.

\section{Dilemmas and the possibility of insurrection}

While the government maintained that they desire to provide the San with modern basic services, they contended that this should be outside of the Reserve. On the other hand, the San maintained they needed development to be taken to their ancestral land within the Reserve. The right to self-determination primarily provides that indigenous people have the right to define and decide on their own development priorities. In this respect, development of the San could not be defined from the perspective of the government of Botswana but from the San people's own perspective. The Botswana Government could not therefore impose its development objectives on the San people. Bojosi (2009) opines that Botswana obliged by Article 8 of the UNDPRS which requires nations to guarantee indigenous people the right to actively participate in decision-making in matters which would affect their rights.

Thus, the decision of the Government of Botswana to remove the San from their land without their consent amounted to forced removal and offended the rights of the San. Yet, the government is mandated to develop its own people, the San included and wishes to do so while respecting state policies. This requires the government to relocate the San before they can enjoy the fruits of development, yet the San are unwilling to leave what they consider to be their ancestral land which is within a game reserve. This is a dilemma which has never been easy to maneuver around by either party. However, what is clear is that the stalemate involves unequal entities. Bearing in mind that Botswana state is center-nerve of almost all development its authority straddles entirely every sphere of life. Ultimately, the state has always used its authority to bypass cardinal principles of democracy in order to 'develop' the San perhaps more-so against their will. Perhaps it is opportune to pose a question: would the Government of Botswana be right to leave the San to their own devices within the Reserve? Could development include the choice not to develop?

Insurgency generally takes the form of organized opposition to authority whereupon a section of the society seeks to wrest power through the overthrow of government (Bujra, 2002). Insurgency may be motivated by a variety of circumstances depending on the socio-economic, political and cultural conditions of those that are aggrieved. This could include lack of or under representation of their community/ethnic group in government, their underdevelopment and suppression, loss of their land and their inability to penetrate the economic sector owing to deliberate state mechanisms. Bujra (2002) further contends that another popular manifestation of insurgency in Africa is secession where the secessionists query their perceived political, economic and cultural oppression. In this case, their wish is to emancipate themselves from oppression either by the state or other established ethnic groups. The San people have queried the denial of their rights to live on their ancestral land. They queried persecution by state specifically their arrest by law enforcement officers for hunting wild game within a game reserve. The San are also up in arms with the government over its decision to terminate services within the Reserve specifically to starve them and coerce them to move out of the Reserve if they desire to enjoy government welfare programs.

The Botswana government's attitudes towards the San, particularly the government determination to assimilate the San into mainstream Tswana societies portends troubled relations with the potential for political instability. A combination of political instability and long standing grievances coupled with the shenanigans of an authoritarian government that is convinced that it is the gatekeeper of a prosperous future for all its people could be a recipe for insurrection.

\section{Conclusion}

The connection between development and democracy lacks universal acknowledgement. Yet, many scholars, both apologists and protagonists, of this symbiotic relationship tend to converge in their acknowledgement of the benefits of having both. Elsewhere in this paper, it has been argued that democracy is pillared on the idea that citizens are the source of authority of government such that the powers of government should be based upon the consent of the governed. However, the case of the development of the San by the Government of Botswana points to the opposite.

Additionally, it has been mentioned that for a majority of the people, democracy is meaningful if it delivers development in the manner in which people want to develop, in the same way as development would be fulfilling if people 
rights, interests and welfare are protected and promoted. Drawing from this paper, it cannot be said that the development of the San as crafted or imposed by the government do reflect their wishes. In this respect, it is safe to conclude that development of the San by the government is an actual a curse to them, specifically that it does not fulfil their aspirations.

\section{References}

Adejumobi, S. 2000. Between democracy and development in Africa: What are the missing links. Paper presented to the World Bank Conference on 'Development thinking in the next millennium'. Paris, 26-28 June 2000.

Bhagwati, J. N. 2002. Democracy and Development: cruel dilemma or symbiotic relationship? Review of Development Economics, 6(2); 151-162.

Bojosi, K. 2009. Country Report of the Research Project by the International Labour Organization and the African Commission on Human and People's Rights on the Constitutional and Legislative protection of the rights of indigenous people - Botswana. Geneva. ILO.

Braun, T. \& Mulvagh, L. 2008. The African human rights system: A guide to indigenous people. Moreton-in-Marsh. Forest People's Programme.

Bujra, A. (Ed.). 2002. Leadership, Civil Society and Democratization: Case studies from Eastern Africa. Nairobi. Development Policy Management Forum.

Chambers, R. 1993. Rural Development: Putting the Last First. Longman, London.

Charlton, R. 1986. Comparative Government. London. Longman.

Chen, L. E. 2007. Development first, democracy later? Or democracy first, development later. The controversy over development and democracy. Paper presented at the annual meeting of the Southern Political Science Association. New Orleans. 3 January, 2007.

Edge, W. A. 1998. Botswana: A developmental state. In Edge, W. A. \& Lekorwe, M. H. (Eds.), Botswana: Politics and Society. Pretoria. J. L. van Schaik.

Esteva, G. 1992. Development. In Sachs, W. (ed.). The Development Dictionary: A to knowledge as power. Johannesburg. Wits University Press.

Johnson, U. 2003. Human rights to development programming. New York. UNICEF.

Kindornay, K. R. 2012. Right Based Approach to development: Implications for NGOs. Human Rights Quarterly, 6(1); 472-506.

Larrain, J. 1989. Theories of Development. Black well Publishers, Cambridge.

Ljungman, C. M. 2004. Applying a right based approach to development: concepts and principles. The winners and losers from right based approaches to development. Conference paper based on a chapter by Ljungman, C. M. In Mikkelsen, B. Methods for development Work and Research- a new guide for practitioners. New Delhi. Sage publications.

Macionis, J. 2008. Sociology: A global introduction. Prentice. Pearson Prentice Hall.

Mealan, F. 2009. Tracking rural change, policy and technology in Australia, New Zealand and Europe. Canberra. ANU press.

Mullick, O. B. 2005. Development theory: Rostow's five stage model of Development and first relevance in globalization. Newcastle. Newcastle University.

Rogers, A. 1992. Adult Learning for Development. Cassel, London.

Saugestad, S. 2004. Indigenous peoples of Southern Africa: An overview. In Hitchcock, R. K. \& Vinding, S. Indigenous People's rights in Southern Africa, IWIGA No 110, Copenhagen.

South Commission. 1990. The challenge to the South: The Report of the South Commission. New York. Oxford University Press.

Theis, J. 2010. Rights based programming: An evolving approach. London. University of London and Action Aid.

UNDP. 1995. Human Development Report. New York. Oxford University Press.

Tsie, B. 1996. The political context of Botswana's development performance. Journal of Southern African studies, 22(4): 599-619.

Wilson, E. F. 2005. Human rights based approach to development: The right to water. Netherlands Quarterly of Human Rights, 23(2); 213-241.

White, R. 1992. Riding the Tiger: The politics of economic reform in post-Mao China. London. Macmillan. 